\title{
Indoor Radon in Northern
}

\section{Virgina: Seasonal Changes and Correlations with Geology}

\author{
by George W. Mushrush, Douglas G. Mose, and Charles E. Chrosinak
}

Radon in homes is a recently recognized hazard of geological origin, regarded in some countries as the second most important cause of lung cancer. In the U.S.A. where up to 20,000 deaths from $\mathrm{Rn}$ ingestion may be now taking place, it is estimated that 8-12\% of American homes have average indoor $\mathrm{Rn}$ levels exceeding the official guidelines. In the U.K. the "action level" is about twice as high as in the U.S.A. and in Sweden over 4 times higher, so that the degree of officially recognized risk is a matter of public policy and perception. The relationship between geology and radon levels is not obvious, for in some parts of the U.S.A. homes built on rocks high in $U$ have indoor $R n$ concentrations much lower than expected. Elsewhere, Rn values have been shown to be influenced by fluctuations in the water table, by soil type, and even by the time of day. As the authors point out here, in Virginia, where much of the research on $\mathrm{Rn}$ has taken place, it is probably more effective to use airborne radioactivity than geology at the surface to gauge regional and seasonal variations in $\mathrm{Rn}$. (Ed.)

\section{Introduction}

The radiation dose from inhaled decay products of ${ }^{222} \mathrm{Rn}$ is the dominant component of natural radiation exposures to the general population (Steinhausler, et al., 1983; Nero, in Nazaross and Nero, 1988). The principal basis for present concern about exposures of radon decay products is the experience with the incidence of lung cancer in underground miners (George and Hinchliffe, 1972; NIOSH, 1985). High fatality rates observed for miners as early as the sixteenth century have been recently ascribed to lung cancer (Nero, 1988). The magniturle of natural radioactivity from racon was not realized until 1984 when the discovery of excessively high levels of radon gas in a home in Boyertown, Pennsylvania, aroused national concern (Lafavore, 1986). The U.S. National Research Council recently supported an earlier estimate by the U.S. Environmental Protection Agency (EPA) that radon exposure leads to 5,000 to 20,000 deaths annually (NRC, 1988).

Upanium in soil and rock is the source of most radon to which the public is exposed. The decay series beginning with $238 \mathrm{U}$ is the major source of natural radiation exposure, with local high levels of uranium due mainly to the underlying rock type and its component minerals. Uranium is more soluble in an oxidizing environment and tends to precipitate in a reducing environment (Levinson, 1980). A significant uranium daughter is $226 \mathrm{Ra}$ with a half-life of 1600 years. Radium follows the chemistry of other Group II elements in the environment. When dissolved in groundwater, raclium is available for chemical reactions that lead to its wide incorporation as insoluble hydroxides and oxides. Radium's daughter, ${ }^{222} \mathrm{Rn}$, is the only radioactive noble gas.
The potential for high radon concentrations depends on the radium and moisture content of the soil, permeability of the soil, the season and the weather. Radon gas enters the atmosphere by crossing the soil-air interface. It is estimated that the emanation rate from soil in the U.S.A. is 0.42 picoCuries ( $\mathrm{pCi}$ ) per $\mathrm{m}^{2}$ per second (NCRP, 1984). The recognition of the importance of soil as a source of indoor radon, combined with the increasing evidence of unacceptably high radon concentrations in a significant number of houses, has raised the question of whether one might predict, on a geological basis, where high levels of indoor radon might be found.

Because of the long half-life of $226 \mathrm{Ra}$ and its lack of chemical reactivity, ${ }^{222} \mathrm{Rn}$ itself acts much like a stable pollutant whose concentration can be determined by comparing the entry and ventilation rates of homes. The decay products are somewhat more complex, but in practical terms the decay product concentration is indicated approximately by the overall radon concentration.

\section{The Fairfax County Survey}

The indoor radon situation as it existed in Fairfax County, Virginia, between November 1986 and November 1987 is described in this paper. This study is still underway, with the number of homes enrolled continually increasing. Data collected more recently confirm the I986-1987 patterns. Approximately 1500 homes are now being monitored, with

TABLE 1: Indoor Radon Measurements in Fairfax County, Virginia (In picocuries per litre - pCi/L)

$\begin{array}{llll} & \text { Median } & \\ \text { Radon } 8 \text { Over } & \text { over } & \text { Number } \\ \text { Season } & \mathrm{pCi} / \mathrm{L} & 4 \mathrm{pCi} / \mathrm{L} & 10 \mathrm{pCi} / \mathrm{l} \text { of llomes }\end{array}$

Basement Indoor Racion

$\begin{array}{lllll}\text { Winter } 1986-87^{1} & 3.9 & 48 & 9 & 283 \\ \text { Spring } 1987^{2} & 2.9 & 32 & 6 & 482 \\ \text { Summer } 1987^{3} & 2.4 & 21 & 2 & 744 \\ \text { Fall } 1987^{4} & 3.0 & 34 & 3 & 743\end{array}$

Sull $1987^{4}$

First Floor Indoor Radon

\begin{tabular}{llll} 
Winter $1986-87^{1}$ & 2.4 & 21 & 5 \\
Spring $1987^{2}$ & 1.6 & 16 & 4 \\
Summer $1987^{3}$ & 1.6 & 11 & 1 \\
Fall $1987^{4}$ & 2.3 & 21 & 0 \\
\hline & & \\
\hline & \\
1) From November 1, 1986 to February 1, 1987 \\
2) From February 1 to May 1, 1987 \\
3) From May 1 to August 1, 1987 \\
4) From August 1 to November 1, 1987
\end{tabular}


about 50 new homes added each month. The total now represents about $0.5 \%$ of the homes in Fairfax County, and the goal is to report on $1 \frac{8}{8}$ of the homes in the area.

The test program requires the homeowner to participate in the entire four season testing period. The homeowner provides an exact location on a county map, so that the geological rock unit underlying the home can be identified and the house located on a map showing airborne radioactivity. A questionnaire requests information on home construction, the type of basement wall, the type of heating system, and many other factors. Specific instructions are given for placing the radon monitor.

The conclusions are based on indoor radon measurements over three month periods using alpha-track radon monitors provided by Tech/Ops Landauer Corporation of Illinois. After the exposure period in the houses, the monitors are returned to the company, where the film in the monitors is developed, the "tracks" produced by the decay of radon progeny near the film surface are measured, and the average amount of indoor radon recorded by the film is calculated. The accuracy of the radon monitors is tested by Tech/Ops Landauer through the EPA Proficiency Program: over the study interval, these tests revealed a $\pm 25 \%$ accuracy at the $90 \%$ confidence level.

\section{Seasonal Variations}

Table 1 is a summary of the observed indoor radon measurements without regard to the geological units under the homes. The comparison between seasons shows that winter is the time of greatest radon concentrations, probably because these houses are then normally closed to outside air. Conversely, summer is the time of lowest radon concentration, presumably reflecting the general increase in the rate of air exchange caused by open windows and doors. About $30 \%$ of the homes have an annual radon concentration above 4 picoCuries per litre ( $\mathrm{pCi} / \mathrm{L}$ ), and spring or fall radon measurements tend to most closely approximate this percentage.

Table 1 also shows that indoor radon on the first floor above the ground is about $30 \%$ less concentrated than in the basement, where the walls are at least partly in contact with the surrounding soil, from which the indoor radon presumably originates. Radon enters the upper levels of a home by diffusion, and by air movement in homes with forced-air heating and cooling systems.

\section{Radon and Regional Geology}

Figure 1 illustrates the three major geological provinees of the Appalachians that underlie Fairfax County (Froehlich, 1985). The Coastal Plain Province, located along the eastern edge of the study area, consists of poorly cemented clastic sediments mostly clay and sand, which were deposited during the opening of the modern Atlantic Ocean. These deposits were formed during the Early Cretaceous Period. The western margin of the county is part of the Culpeper Basin, a fault-bounded valley containing terrestrial clastic (siltstone, sandstone, conglomerate) along with extrusives and intrusives (diabase) all of mainly Jurassic age (190-150 $\mathrm{Va}$ a). Separating these two regions is the Piedmont Province, which extends from Maryland to Georgia, and which is composed of metamorphic and igneous rocks mainly of Paleozoic age (latest Precambrian to Devonian), formed when the Appalachian mountains were created.

Table 2 shows that the metamorphic and igneous rocks of the Piedmont correlate consistently with the highest percentage of homes with radon above $4 \mathrm{pCi} / \mathrm{L}$, reaching a
Radon is a chemically inert radioactive gas produced by the decay of uranium in the ground, which in turn produces its own radioactive decay products. When we breathe, the radon decay products are deposited in the lungs and respiratory tracts. The main villains are the two polonium isotopes that emit alpha-particles - helium nuclei. They lose their energy in a very short distance, causing considerable damage to the cells they hit. These decay products all have short half-lives of up to 27 minutes before they decay to a long-lived isotope of lead, which is of no health significance in low concentrations.

Virtually any soil or broken rock has enough radon in its interstitial volume to cause a potential problem provided there is an easy pathway into the home. Radon measuring devices can monitor the concentration of radon by means of the alpha or gamma-ray emission of the radon daughters. However, there are problems associated with measuring the values in a house, because the radon concentrations can vary with time.

Figure A shows the daily variation of radon decay products found in a home near Ottawa, Canada (personal communication, Ian Thomson, 1988). A grab sample is thus not likely to be representative of the average levels present. There are also seasonal variations, the values generally being higher in the winter when the house is shut and the ventilation is lower. The difference between the inside and outside temperatures causes a lower pressure inside the house as compared to the outside; soil gases can thus be sucked in from the ground via small cracks and other openings in the basement walls and floors.

Public concern over radon in the United States started about four years ago in the Reading Prong of Pennsylvania, a basement complex containing several areas where uranium concentrations are unusually high. A worker in a local nuclear power station began to trigger the alarm on the plant's radiation detector. Close examination showed that his home

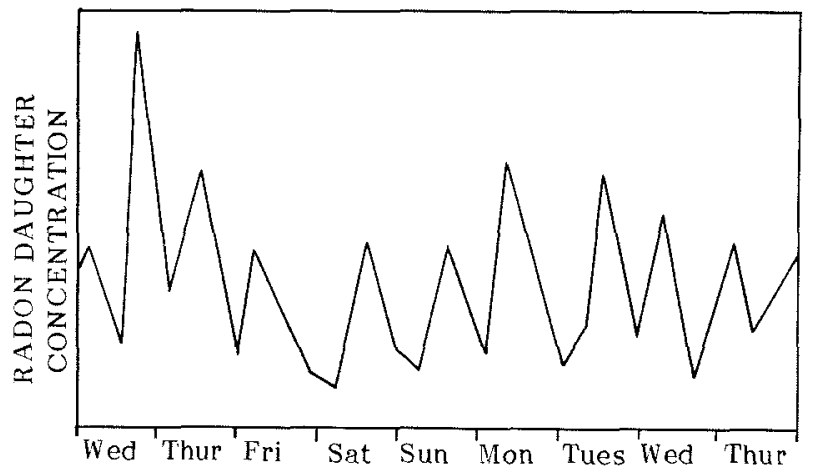

Figure A: Daily variations of radon levels in a house near ottawa, Canada.

was contaminated with unusually high concentrations of radon. It was estimated that he was receiving a radiation dose equivalent to a chest X-ray every 20 seconds throughout the year. It has since been shown that his home, which had the highest radon level for any house found anywhere, and some houses nearby, also high in radon, are situated in an area of fractured and porous rock that is high in uranium.

In southwestern England radon levels are about ten times the national average in homes built on granites that are generally high in uranium, which is the source of the radon. And in Finland high radon levels are related to Rapakivi granites in the southeastern part of the country, though the incidences of lung cancer do not correlate with radon in the homes here.

- R.L. Grasty, Geological Survey of Canada, Ottawa 


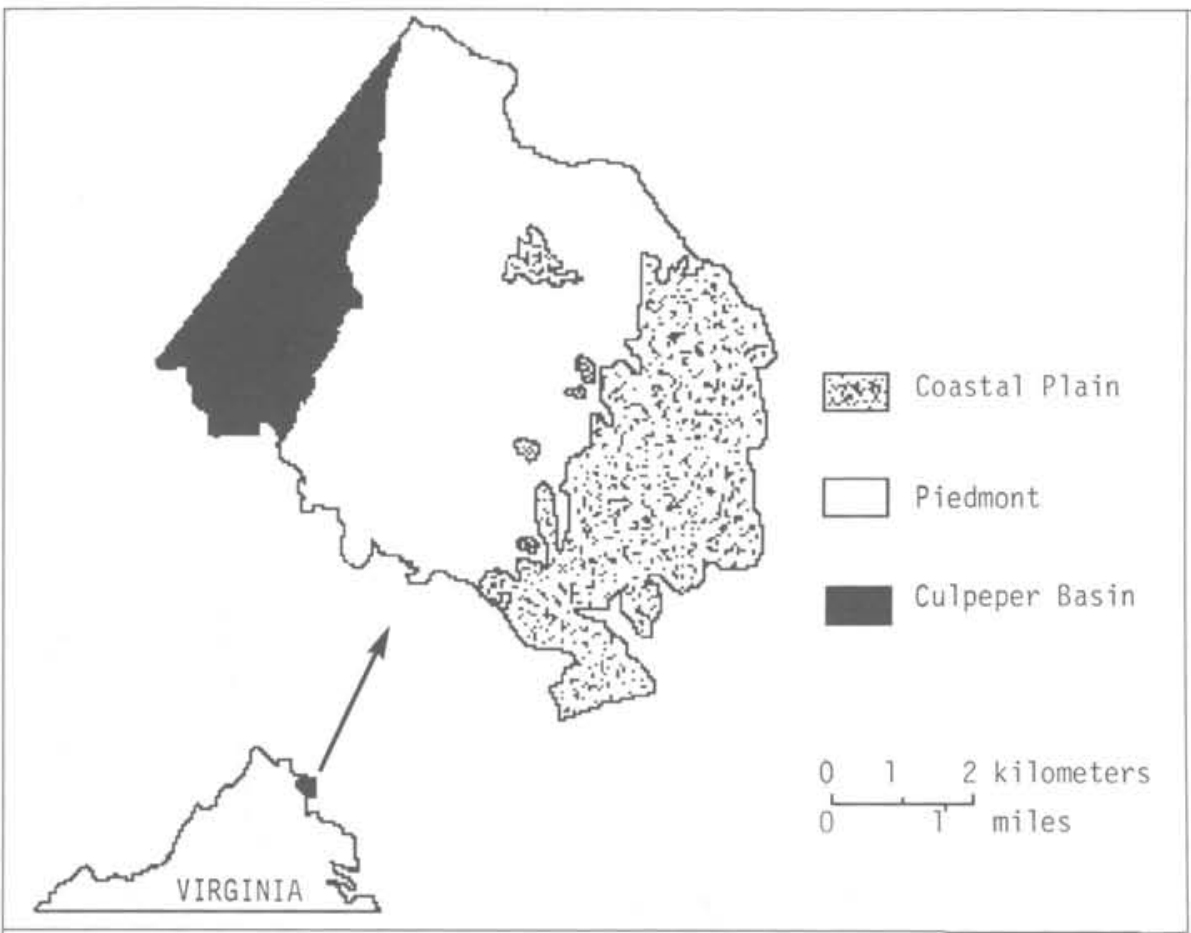

response of the scintillation equipment is approximately 1000 feet in diameter, and the signal is generated by the uppermost one foot of soil and rock cover. The combination of elose flight lines and area of response is such that essentially all of the ground surface was examined for its radioactivity signal.

This type of survey is potentially very useful, though there are some disadvantages. One problem is that the total surface is examined, including water and man-made structures such as pavements and buildings. However, these comprise only a small percentage of the total land surface. Another consideration, at least for radon surveys, is that the measurements are of total gamma-ray radioactivity, derived from ${ }^{21} 4 \mathrm{Bi} \quad$ (a radioactive daughter of uranium, produced by the decay of $222 \mathrm{Rn}$ ), thorium and potassium. To a rough approximation, however, uranium, thorium and potassium tend to have a similar geochemical behaviour, with rocks rich in the latter tending to be enriched in uranium and thorium. Furthermore, as shown in Table 3 , there

Figure 1: The three major geological provinces of Fairfax County, northern Virginia.

maximum of more than $50 \%$ of the Piedmont homes during the winter of 1986-1987. Presumably this is a consequence of uranium enhancement that is characteristic of rocks produced during mountain building events (Speer et al., 1981). The sedimentary strata of the Coastal Plain are associated with the lowest percentage of homes above 4 $\mathrm{pCi} / \mathrm{L}$ : only about 108 of the homes have an annual indoor radon concentration above this level. This low percentage probably results because the fluvial and shallow marine sands that comprise most of the sedimentary strata were naturally depleted in uranium during their residence time in aqueous environments. The sedimentary rocks that make up most of the Culpeper Basin are composed of less weathered detritus, which could account for the somewhat elevated percentage of homes above $4 \mathrm{pCi} / \mathrm{L}$ here compared to the homes on the Coastal Plain.

\section{Using Airborne Radiation}

The radiation signal of the Earth's surface in our study area is rather better known than anywhere else in Virginia (Fig. 2). The total measurements of gamma-ray radioactivity were made during flights about 500 feet above ground along east-west flight lines, spaced $1 / 2$ mile apart (Daniels, 1980). At this altitude the effective area of

TABLE 2: Indoor Radon in Fairfax County By Geological Provinces

\begin{tabular}{|c|c|c|c|c|c|}
\hline Season & $\begin{array}{l}\text { Geological } \\
\text { Province }\end{array}$ & $\begin{array}{l}\text { Median } \\
\text { Radon } \\
(\mathrm{pCl} / \mathrm{L})\end{array}$ & $\begin{array}{l}8 \text { Over } \\
4 \mathrm{pCi} / \mathrm{L}\end{array}$ & $\begin{array}{l}80 \text { ver } \\
10 \mathrm{pCi} / \mathrm{L}\end{array}$ & $\begin{array}{l}\text { Number } \\
\text { of Homes }\end{array}$ \\
\hline \multicolumn{6}{|l|}{ 1986-87: } \\
\hline \multirow[t]{3}{*}{ Winter } & Culpeper Basin & 3.7 & 42 & 3 & 31 \\
\hline & Piedmont & 4.1 & 53 & 11 & 224 \\
\hline & Coastal Plain & 2.6 & 18 & 4 & 28 \\
\hline \multicolumn{6}{|l|}{ 1987: } \\
\hline \multirow[t]{3}{*}{ Spring } & Culpeper Basin & 2.9 & 26 & 5 & 57 \\
\hline & Peidmont & 3.1 & 36 & 7 & 376 \\
\hline & Coastal Plain & 1.7 & 12 & 0 & 49 \\
\hline \multirow[t]{3}{*}{ Summer } & Culpeper Basin & 2.0 & 11 & 4 & 72 \\
\hline & Piedmont & 2.7 & 24 & 2 & 577 \\
\hline & Coastal Plain & 1.7 & 6 & 0 & 95 \\
\hline \multirow[t]{3}{*}{ Fall } & Culpeper Basin & 2.6 & 27 & 1 & 71 \\
\hline & Piedmont & 3.4 & 37 & 4 & 577 \\
\hline & Coastal Plain & 2.1 & 8 & 0 & 95 \\
\hline
\end{tabular}
is a good correlation between indoor radon and the total gamma-ray signal, suggesting that the component of the total signal due to $222 \mathrm{Rn}$ is a relatively constant percentage of the total signal. The correlation persists through all seasons, even though the homes are typically tightly closed to outside air only during the winter.

TABLE 3: Aeroradioactivity Versus Indoor Radon in Fairfax County

\begin{tabular}{|c|c|c|c|c|c|c|}
\hline Aeroradioaetivity & $\begin{array}{l}\text { Total } \\
\text { Homes }\end{array}$ & $\begin{array}{l}\text { Median Rn } \\
\text { In Homes } \\
(\mathrm{pCi} / \mathrm{L})\end{array}$ & $\begin{array}{l}8 \text { Over } \\
4 \mathrm{pCi} / \mathrm{L}\end{array}$ & $\begin{array}{l}\text { Total } \\
\text { Homes }\end{array}$ & $\begin{array}{c}\text { Median } \mathrm{Rn} \\
\text { In Homes } \\
(\mathrm{pCi} / \mathrm{L})\end{array}$ & $\begin{array}{l}8 \text { Over } \\
4 \mathrm{pCi} / \mathrm{L}\end{array}$ \\
\hline & & Winter & & & Summer & \\
\hline Less than 200 eps & 10 & 2.2 & 10 & 55 & 2.1 & 16 \\
\hline $200-300$ eps & 54 & 2.5 & 31 & 149 & 2.1 & 20 \\
\hline $300-400$ eps & 106 & 4.2 & 55 & 266 & 2.6 & 22 \\
\hline $400-500 \mathrm{cps}$ & 62 & 5.5 & 55 & 94 & 3.1 & 36 \\
\hline \multirow[t]{2}{*}{ Above $500 \mathrm{cps}$} & 2 & 10.1 & 100 & 8 & 3.7 & 63 \\
\hline & & Spring & & & Fall & \\
\hline Less than $200 \mathrm{cps}$ & 32 & 2.3 & 16 & 51 & 2.5 & 24 \\
\hline $200-300$ eps & 92 & 2.3 & 24 & 154 & 2.5 & 25 \\
\hline $300-400$ eps & 171 & 3.2 & 37 & 267 & 3.4 & 38 \\
\hline $400-500 \mathrm{cps}$ & 72 & 3.5 & 46 & 94 & 4.5 & 56 \\
\hline Above 500 eps & 5 & 6.0 & 83 & 7 & 5.4 & 86 \\
\hline
\end{tabular}

Perhaps the most significant advantage of the Fairfax County airborne radioactivity surveys is that they cover most of the surface of the county. This makes such surveys a cost-effective improvement over an analagous land-based study in which a geologist would examine the radon emanation characteristics of all the area underlain by each geological unit. A comparable land-based study mainly on geological units and soil types would probably be less'useful because, as can be demonstrated by comparing geological maps with aeroradioactivity maps for the study area (compare Fig. 1 and Fig. 2), most rock units vary in surface radioactivity.

\section{Conclusions}

Indoor radon and its progeny are a serious problem in northern Virginia, and elsewhere. In the present study, the indoor radon concentrations can be related to the season, the presence of a basement, the geology, and the aeroradio- 


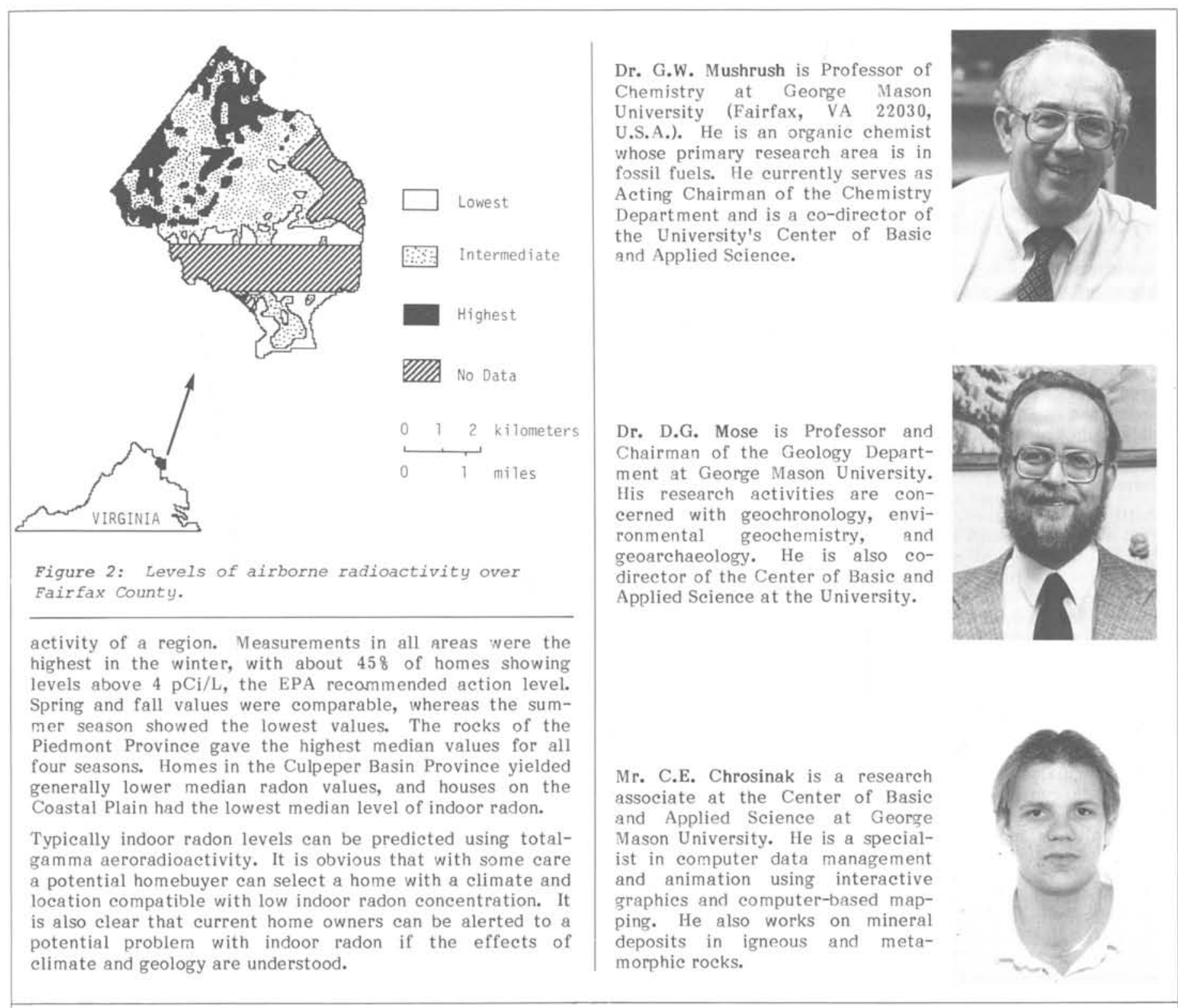

\section{References}

Daniels, D.L., 1980. Geophysical-geological analysis of Fairfax County, Virginia. U.S. Geological Survey, Report 80-1165, 64p.

Froelich, A.J., 1985. Folio of geologic and hydrologic maps for land use planning in the coastal plain of Fairfax County and vicinity, Virginia. U.S. Geological Survey Miscellaneous Investigations Series, Map I-1423.

George, A.C. and Hinchliffe, L., 1972. Measurement of uncombined radon daughters in uranium mines. Health Physies, v. 23, no. 6, p. 791-803.

Lafavore, M., 1986. Radon the Invisible Threat: What it is, Where it is, How to Keep Your House Safe. Rodale Press, Emmaus, $\mathrm{Pa}, 256 \mathrm{p}$.

Levinson, A.A., 1980. Introduction to Exploration Geochemistry, Wilmette Illinois. Applied Publishing Ltd., $924 \mathrm{p}$.

Nazaross, W.W. and Nero, A.V. Jr., 1988. Radon and its Decay Products in Indoor Air. John Wiley and Sons, New York, $518 \mathrm{p}$.

NCRP (National Council on Radiation Protection and Measurements), 1984. Exposures from the Uranium Series

with Emphasis on Radon and its Daughters. Report No. 77, $131 \mathrm{p}$.

NIOSH (National Institute for Occupational Safety and Health), 1985. Evaluation of Epidemiologic Studies Examining the Lung Cancer Mortality of Underground Miners. Cincinnati, Ohio, May 9, 1985, 80p.

NRC (National Research Council Committee on the Biological Effects of Ionizing Radiation), 1988. Health Risks of Radon and Other Internally Deposited Alpha-emitters. National Academy Press, Washington, D.C., 602p.

Speer, J.A., Solberg, T.N. and Becker, S.W., 1981. Petrography of the uranium-bearing minerals of the Liberty Hill Pluton, South Carolina, phase assemblages and migration of uranium in granitoid rocks. Economic Geology, v. 76 , no. 8 , p. $2162-2175$.

Steinhausler, F.W., Hoffman, W., Pohl, E. and Phol-Ruling, J., 1983. Radiation exposure of the respiratory tract and associated carcinogenic risk due to inhaled radon daughters. Health Physics, v. 45 , no. 2, p. 331-337. 